\title{
Challenges of Care giving Alzheimer's Patients
}

\author{
Vijayalakshmi, $\mathrm{K}^{1}$, C. G. Venkatesha Murthy ${ }^{2}$
}

\section{ABSTRACT}

The present review paper attempts to present the challenges faced by the caregivers when they assume care giving responsibilities for person/s affected with Alzheimer's. The experiences in the context of care are not limited with physical and psychological domains alone. Rather care giving for Alzheimer's involves increased risk of mental, emotional and economic problems as well as due to consequences of care giving that accompanies due to handling such a role. Ultimately the quality of care received by the person with Alzheimer's and the quality of life of the caregiver becomes imbalance/impaired. Successful execution of the role in care giving brings harmony/balance in life between them in all dimensions of health which is highly essential. Therefore it demands the professionals to help the caregivers to understand about Alzheimer's disease condition and to handle them based on felt- need to render the best care.

Keywords: Alzheimer's Disease, Epidemiology, Characteristics, Challenges of Care Giving, Strategies for Caregivers

Alzheimer's disease (AD) is a chronic, progressive, fatal, degenerative disease of the brain that ultimately results in dementia. Alzheimer's is one of the three terrible Central Nervous System degenerative diseases i.e., Alzheimer's, Parkinson and Huntingtons as per the International Classification of Diseases ICD-10 ${ }^{\text {th }}$ edition (WHO) and Clinical Classification of the degenerative diseases of the nervous system.

The other terms of Alzheimer's disease (AD), a silent killer of the minds are Senile Dementia or Alzheimer Disease Related Disorder (ADRD), Senile Dementia Alzheimer Type (SDAT), and Pre-senile Dementia as seen in the ages of 40s and 50s also.

Historically, a century ago this mind robber degenerative disease was first studied, presented and published by German Psychiatrist Alois Alzheimer (1864-1915) and was named after him. In 1910, Emil Kraepelin, German Psychiatrist coined and published in the eighth edition of his Textbook of Psychiatry the term "Alzheimer disease".

Clinically, Alzheimer's disease is pathologically characterized by the formation of abnormal structures in the brain, or beta-amyloid protein deposits, called plaques and tangles. Damage

\footnotetext{
${ }^{1}$ Research Scholar, University of Mysore, Mysore

${ }^{2}$ Prof. of Education, Regional Institute of Education, Manasa Gangotri, Mysore

*Corresponding Author

(c) 2015 I Vijayalakshmi k, V Murthy; licensee IJIP. This is an Open Access Research distributed under the terms of the Creative Commons Attribution License (http://creativecommons.org/licenses/by/2.0), which permits unrestricted use, distribution, and reproduction in any Medium, provided the original work is properly cited.
} 


\section{Challenges of Care giving Alzheimer's Patients}

typically begins in hippocampus, area of cerebrum which is responsible for formation of new memories. Plaques and tangles spread forward to temporal and frontal lobes affecting language, judgment, learning, comprehension, orientation and emotions.

Alzheimer's disease is thus observed with loss of cognitive function. Alzheimer's disease is manifested by loss of recent memory for events, persons and places. Over time, they get increasingly confused and disoriented; also results in restriction of daily activities i.e. physical deterioration and in most cases, leads to the need of long term care till death occurs. The symptoms progress from mild cognitive and non-cognitive problems such as memory loss to total elimination of possibility of independent living. As the disease progresses, all the symptoms become apparent. (http://en. wikipedia.org /wiki /Alzheimer \%27s-disease).

Alzheimer's disease course is divided into four stages, with progressive patterns of cognitive and functional impairments. They are pre-dementia, early (mild), moderate and advanced/severe (last) stage of Alzheimer's disease. In the last stage the patient is totally dependent upon caregivers. A definite diagnosis is usually made once cognitive impairment compromises Activities of Daily Living (ADL) but still the patient lives independently. The rate of progression from mild to late is highly variable from individual to individual and ranges from 3 to 20 years (Lewis, S \& et.al, 2007).

\section{ALZHEIMER'S CONTINUM- CONDITION AND CARE GIVING}

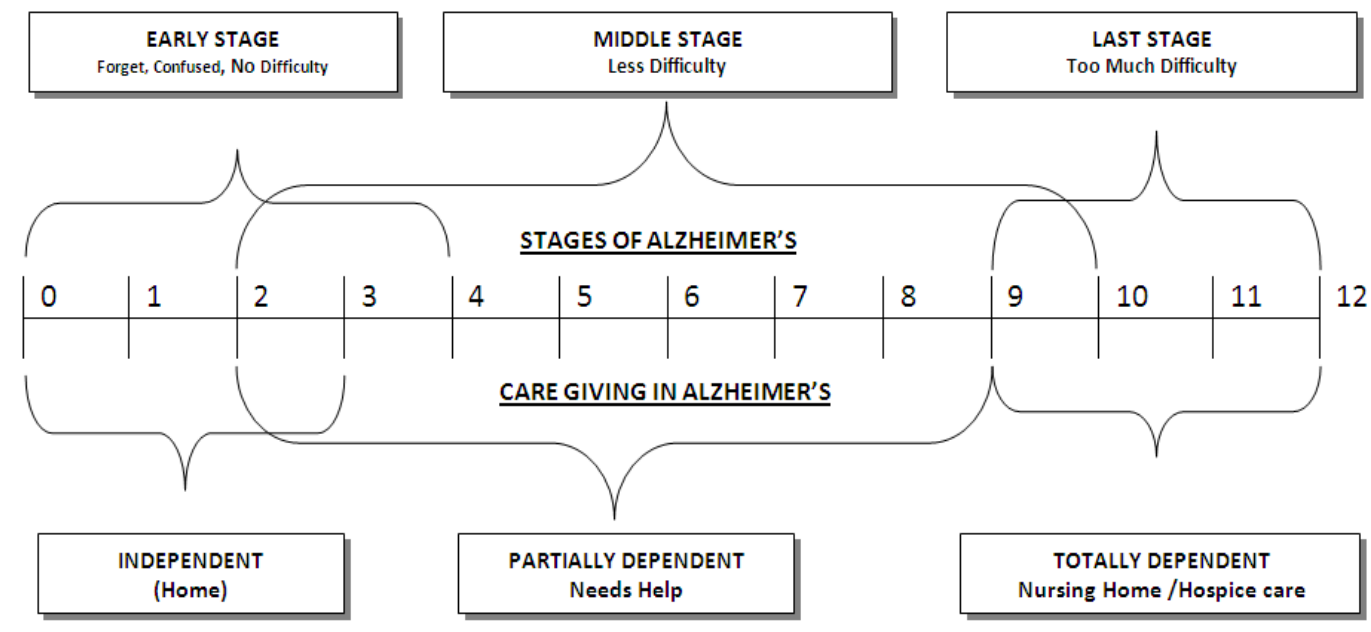

Alzheimer's is the important feature and commonest cause of dementia in the elderly of age over 65 years. Significant advances in research identified Alzheimer's disease is caused by reduced synthesis of the neurotransmitter acetylcholine. Genetic, lifestyle, and environmental factors are risk factors of Alzheimer's, an insidious disease. (http://en.wikipedia.org/wiki/Alzheimer\%27sdisease). Age is the primary risk factor for the Alzheimer's disease. The causes of dementia are varied. Alzheimer's disease (AD) causing dementia is irreversible (http://www.wikio.com/article/74017358). 
Alzheimer's disease in India: In India, a multicenter survey sponsored by the WHO, estimated the prevalence of dementia in elderly above 65 years as 27/1000 in urban and 35/1000 in rural populations, respectively. Around 35-40\% of these diagnosed were as Alzheimer's disease (Rajkumar, 2008). The chairman of Alzheimer's Disease International and founder of Alzheimer's and Related Disorders Society of India (ARDSI) stated the prevalence of the Alzheimer's disease is said to be one in 20 for people over 80 years in India. There are about 3.7 crore people affected by the disease, and the cost of treating the disease is pegged at Rs.14, 700 crore. The number with treble by next 20 years and double as 7.6 crore (Jacob, 2011).

\section{Characteristic problems of Alzheimer's patient:}

\begin{tabular}{|c|c|c|c|}
\hline Problems & Mild/early stage & $\begin{array}{l}\text { Moderate/middle } \\
\text { stage }\end{array}$ & Severe /late stage \\
\hline $\begin{array}{l}\text { Difficulty with } \\
\text { familiar place and } \\
\text { objects: inside the } \\
\text { home and outside the } \\
\text { home: }\end{array}$ & Less difficulty & $\begin{array}{l}\text { Difficulty is well } \\
\text { pronounced }\end{array}$ & $\begin{array}{l}\text { Too much difficulty } \\
\text { to recognize, to } \\
\text { know, to recall, to } \\
\text { judge, to perceives } \\
\text { and to communicate } \\
\text { about self , familiar } \\
\text { people and others . }\end{array}$ \\
\hline Loss of memory & $\begin{array}{l}\text { Vague memory ,has } \\
\text { trouble to remember, } \\
\text { lose things }\end{array}$ & $\begin{array}{l}\text { Obvious memory } \\
\text { Problems, confused } \\
\text { on and off related to } \\
\text { routines, name, } \\
\text { events etc }\end{array}$ & $\begin{array}{l}\text { Total Forgetting, } \\
\text { fragmented memory }\end{array}$ \\
\hline Difficulty in speech: & $\begin{array}{l}\text { No difficulty, can't } \\
\text { initiate sentence, } \\
\text { Repeats words, } \\
\text { actions }\end{array}$ & \begin{tabular}{l}
\multicolumn{2}{l}{ Skips or miss words, } \\
Struggles $\quad$ with \\
initiating \\
formation
\end{tabular} & $\begin{array}{l}\text { Absence of speech, } \\
\text { Stops conversation }\end{array}$ \\
\hline Difficulty in walking & No difficulty in gait & $\begin{array}{l}\text { Confused to walks, } \\
\text { jumps, runs, sits } \\
\text { instead of standing } \\
\text { etc }\end{array}$ & $\begin{array}{l}\text { Confined to bed, } \\
\text { aimless movement }\end{array}$ \\
\hline $\begin{array}{l}\text { Difficulty in } \\
\text { elimination related to } \\
\text { bowel and bladder } \\
\text { control }\end{array}$ & No difficulty & More difficulty & Bed wetting \\
\hline $\begin{array}{l}\text { Difficulty in eating } \\
\text { and swallowing: }\end{array}$ & No difficulty & Confused & $\begin{array}{l}\text { Forgets to swallow, } \\
\text { stops solid foods }\end{array}$ \\
\hline
\end{tabular}




\section{Challenges of Care giving Alzheimer's Patients}

\begin{tabular}{|c|c|c|c|}
\hline $\begin{array}{l}\text { Loss of interest in } \\
\text { hobbies and activities }\end{array}$ & No difficulty & Confused & $\begin{array}{l}\text { Slowly progresses } \\
\text { with struggling and } \\
\text { stopping to execute } \\
\text { the routine }\end{array}$ \\
\hline Loss of motivation & No difficulty & $\begin{array}{l}\text { Needs stimuli } \text { to } \\
\text { respond }\end{array}$ & $\begin{array}{l}\text { Slowly proceeds with } \\
\text { decrease in } \\
\text { motivation, stimuli } \\
\text { and becomes dull, } \\
\text { refuses, hesitates and } \\
\text { forgets and no } \\
\text { interest }\end{array}$ \\
\hline Changes in behaviour & No change & Less changes & $\begin{array}{l}\text { Shows deviation } \\
\text { from normal level of } \\
\text { functioning to } \\
\text { depression, anxiety, } \\
\text { irritability, } \\
\text { repetitiveness, anger, } \\
\text { confusions, } \\
\text { agitations, sleep, } \\
\text { hallucinations, } \\
\text { wandering and gets } \\
\text { lost. }\end{array}$ \\
\hline $\begin{array}{l}\text { Disorientation in } \\
\text { time, place and } \\
\text { person } \\
\text { Calendar,date, } \\
\text { month,year, time }\end{array}$ & Can be oriented & Confused & $\begin{array}{l}\text { Disoriented and } \\
\text { Exhibits difficulty } \\
\text { and failure to } \\
\text { recognize morning, } \\
\text { evening, friends and } \\
\text { relatives and places } \\
\text { like church, temple. }\end{array}$ \\
\hline $\begin{array}{l}\text { Difficulty in making } \\
\text { decisions }\end{array}$ & No difficulty & More difficulty & Unable to calculate \\
\hline $\begin{array}{l}\text { Understanding and } \\
\text { interpretation } \\
\text { events like birth, } \\
\text { death etc, }\end{array}$ & No difficulty & Confused & Too difficult \\
\hline Difficulty in coping & $\begin{array}{l}\text { Coping is satisfactory } \\
\text { but had starting } \\
\text { trouble }\end{array}$ & $\begin{array}{l}\text { Irritated, decreased } \\
\text { ability and can do } \\
\text { with commands and } \\
\text { instructions }\end{array}$ & $\begin{array}{l}\text { Can not follow and } \\
\text { execute the daily } \\
\text { routines }\end{array}$ \\
\hline
\end{tabular}




\section{CHALLENGES OF CARE GIVING:}

Alzheimer's patients cannot manage their personal life without the support and care of someone who is close to them, called 'caregivers'. A Caregiver is broadly defined as one who provides informal care to a family member -including basic Activities of Daily Living (ADL) such as bathing and dressing or Instrumental Activities of Daily Living (IADLs) such as cooking and housework (http:/wwwannalsoflongtermcare.com/article/4000).

Alzheimer's disease creates enormous strain and burden for family caregivers. Caregivers may experience high levels of burden (Scholte, et al, 1998). Wasow, \& Coons, (1987) indicated that the grief of caregivers of Alzheimer's disease often remain undetected by society. Grief and loss are combined with feelings of stigma are often associated with disease (Walker, Pomeroy, McNeil, \& Franklin, 1994). Alzheimer's caregivers report that they frequently experience high level of stress. Too much stress can be damaging to both a caregiver and the person with Alzheimer's. Symptoms of caregiver stress include denial, anger, social withdrawal, anxiety, depression, exhaustion, sleeplessness, irritability, lack of concentration and health problems.

The care giving is associated with increased morbidity and mortality among caregivers; up to $50 \%$ of caregivers of patients with dementia develop psychiatric symptoms during the course of their care giving. (www.cfp.ca/cgi/content/full/54/7/1008). One in eight will become ill or injured as a direct result of caregiving, and one in three uses medications for caregiving-related difficulties.(http:/www. thefreelibrary. com/The+ devastating+toll+of + Alzheimer's + disease+on+patients...).

Informal caregivers have reported a variety of detrimental physical and emotional effects that challenge their ability to continue caring for their relative (Lim, \& Zebrack, 2004). Care giving may be a risk factor for early mortality perhaps because of effects of chronic stress, not taking care of own health, and care giving worsens (Gwyther, 2011). Care giving also implies distress for patients and families, and economic loss in the form of cost entailed in the long term care. Alzheimer's disease-care giving has significant social and financial costs (Gutterman, et al. 1999., Leon, \& Neumann, 1998., and Small, et al, 1997). Thus the authors project the challenges and the afflictions of the caregivers with the survey of literature.

Strategies for caregivers: The authors propose different strategies which could be used for care givers. They include, Role Reversal, Biofeedback, and Psycho-education.

\section{(a) Role reversal:}

"Role reversal involves the changing of positions between the protagonist and his significant other, such as family members, friends, or people in school or in workplace. The protagonist is invited to show the posture, the way of speaking, the behaviour, the emotion, the attitude, and any other information of his significant other" (https://en.wikipedia. Org/ wiki/ Role_reversal). This technique helps the protagonist explore any information of the other role. Role reversal is a frequent phenomenon in the family dynamics of care giving situations (Salmanson, \& Robbins, 


\section{Challenges of Care giving Alzheimer's Patients}

2003). Hogan, et al (2004) conducted a recent phenomenological research which involved examined role changes experienced by family caregivers of individuals with Alzheimer's disease. Kudos et al.'s, (2004), qualitative study explored the phenomenon of role change as experienced by family caregivers of adults with Alzheimer's disease. Cadena Christine (2007) contributes content of implications for Role Reversal and Couples Therapy of Alzheimer's Disease. Role reversal is a powerful technique which can provide insights into understanding the significant other with their intends and actions. This can be an effective intervention among caregivers of Alzheimer's patients.

(b) Biofeedback: It is a process of becoming aware of various physiological functions using instruments that provide information on the activity of those same systems, with a goal of being able to manipulate them at will. It is a technique of self-regulation of awareness states by the subject. Bio-feedback- Galvanic Skin Response (GSR) is a form of biofeedback based on reading from sensors. Kalantari,(2010) Conducted a study to assess the effectiveness of biofeedback on anxiety and stress among cancer patients of two stages and their caregivers and found to be effective with continued five days of intervention. Zoë, et al., (2010) reviewed the negative effects of teacher stress and suggested coping for teacher stress with Biofeedback training for Pacific educators. Ganster, et al (1982); Bruning \& Frew (1987); Reynolds, et al (1993); Milstein, \& Golaszewski (1985); Cooley \& Yovanoff (1986); Forman (1981); Kagan, Kagan, and Watson (1995) and Higgins (1986) emphasize the importance of physiological training body control in stress management.Biofeedback can be used effectively with the caregivers of Alzheimer's patients.

(c) Psycho-education: Psycho-education is regarded as a specific form of psychotherapy (Bauml, et al., 2006), which can be designed to be a part of overall treatment plans. The main principle of psycho-education is that everyone has the right to receive information about the illness and treatment in order to take more active role in relation to illness instead of being a passive recipient of care (Cross, \& Kirby, 2001; Deegan, 1996; McGorry, \& Edwards, 1997; and Muesar, et al., 2002). The most common being educational programme (face-to-face, on-line, software or published guidelines), frequent monitoring phone calls, self-help group's seminars, and support groups. Psycho-education can be group-based, family-based, parent-based or individually implemented. If caregivers are educated, they can feel relaxed and in control of their condition. Donker Tara et. al's (2009) meta analysis focused on two types of psycho-educational interventions like active and passive and showed that brief passive psycho-educational intervention for depression and psychological distress reduces symptoms of mental disorders. The passive psycho-education is one which provides information, education materials or feedback/advice. Beynon et al's. (2008) systematic review and meta-analysis of controlled trials showed group psycho-education to be effective for relapse prevention. 


\section{Challenges of Care giving Alzheimer's Patients}

\section{CONCLUSION}

The present paper is an attempt to identify the literature that explored problems specially faced by caregivers of Alzheimer's. The survey/ review reveal that the elderly has more risk to live with dementia. The magnitude of the disease is increasing day by day due to various changing social dynamics. The victims of Alzheimer's disease are both the patient and the caregiver. Caring to an Alzheimer's disease patient affects an individual and the family in many ways. The care of a family member with Alzheimer's disease demands a range of skills, patience, good health and mental ability to cope with continued stress. Family members need information about Alzheimer's disease and build capacity to handle them to promote change in their daily lives. The probe on this area is found less. Researchers have a special role, a great concern and responsibility to understand and work for best coping by improving life style. Further, it is hoped that more research in this area will address and will highlight the effective resources for caregivers.

\section{REFERENCES}

Alzhemier's Disease -Wikipedia, the free encyclopedia (2010). Retrieved June 1, 2011, from Retrieved October 29, 2010, from http://www.alz.org/living-with-alzhemiers-caregiverstress-lwa.asp

Alzhemier’s Disease -Wikipedia, the free encyclopedia (2011). Retrieved June 1, 2011, from http://en.wikipedia.org/wiki/Alzhemiers\%27s_disease

Alzhemier's Association-Caregiver Stress. Retrieved October 29, 2010, from http://www.alz.org/living-with-alzhemiers-caregiver-stress-lwa.asp

Alzhemier's Caregivers:MedlinePlusUs National Library of Medcine(NIH). Retrieved October 29, 2010, from http://www.nln.nih.gov/medlineplus/alzhemierscaregivers.html

Alzhemier's Australia NSW (2009). Alzhemier's News....Keeping you informed. Retrieved March 3, 2011, from http://alznews.blogspot.com/

Alzhemier's Disease Education \& Referral Center. Caregiver Guide. Retrieved on November, 11, 2010, from http://www.nia.nih.gov/alzhemiers/Publications/caregiverguide.htm

Alzhemier's Disease Statistics (December 9, 2009). Retrieved December 20, 2010, From

http://www.alzhemiersredingroom.com/p/alzhemiers-statistics.html

Alzhemier’s Disease Statistics:Facts and Figures: (December 9, 2010). Alzhemier’s Reading Room Retrieved December 20, 2010,

From http://www.alzhemiersredingroom.com/p/alzhemiers-statistics.html

Alzhemier's Disease :Facts and Figures: (2015).1131332. Alzhemiers \& Dementia:Alzhemier's Association .

Alzhemier's Disease Statistics: Facts and Figures: (2014). Alzhemier's Association: Alzhemiers \& Dementia-The brains behind saving yours. 10, (2).

Alzhemier's Reading Room. Are Alzhemier's Caregivers the Forgotten? Retrieved on December, 15, 2010, from http://www.alzhemiersredingroom.com/2009/4are-alzhemierscaregiver-forgotten.html 
Alzhemier's Research Trust: Dementia statistics UK. Retrieved March, 18, 2010, from http://www.alzhemiers—research.org.uk/info/statistics

A Brief History of Alzhemier's Disease. Retrieved Jan 6, 2011, from http://www.caregiver.com/channels/alz/articles/a_brief_history.htm

The history of 'Alzhemier's Disease'|The Human Genome. Retrieved Jan 6, 2011, from http://genome.wellcome.ac.uk/doc_WTD020951.html

Andreshed B. (2006). Relatives in end -of-life care -part 1: A systematic review of the literature the five last years January 1999- February 2004. Journal of Clinical Nursing, 15 (9), 1158-1169.

Beck C. K. (1998).Psychosocial and behavioral interventions for Alzheimer's Disease patients and their families. American Journal of Geriatric Psychiatry. 6 (2-1), S41-8.

Callion P.M, Tideland, R.W. \& Freeman, K. (1999). An evaluation of family visit education program Journal of the American Geriatrics Society, 47(2), 203-214.CaregiverWikipedia, the free enyclopedia oct 29.2010. Retrieved from http://en.wikipedia.org/wiki/Caregiver

Caregiving in America Fact Sheet. Alzhemier's Reading Room(Dec 9,2009) retrieved from http://ping.fm/pkSq0

Caregiving and Alzheimer's disease (2004)-Free Online Library. National women's Health Report.Retrievedfromhttp://www.thefreelibrary.com/Caregiving\%26+Alzheimer's+disea sea014781292.

Caregiver-Wikipedia, the free encyclopedia. Retrieved Jan 6, 2011, from http://en.wikipedia.org/wiki/Caregiver

Caregiver-Wikipedia, the free encyclopedia. Retrieved Oct 29, 2010, from http://en.wikipedia.org/wiki/Caregiver

Dunkin, J.J \& Anderson-Hanley, C. (1998).Dementia Caregiver burden: A review of the literature and

Guidelines for assessment and Intervention. Neurology, 51(1), S53-S60.

FCA: Selected Caregiver Statistics.Family Caregiver Alliance. Retrived Oct 28 (2010) from http://www.caregiver.org/caregiver/jsp/content_node.jsp?nodeid=439

Facts for health—alzhemier's—history of the disease. Retrived Jan 6, 2011, from http://www. Alzhemiers.factsforhealth.org/what/history.asp

Gallagher -Thompson, D, Lovett, S., Rose, J, et al. (2000). Impact of psycho educational intervention on distressed family caregivers. J Clinical Geropsychol ,6:91-110.

Greenson R.R, (1960).To empathize means to share to experience the felling of person empathy and its vicissitudes. International Journal of Psychoanalysis.41,418-424.

Haley, W.E. (1997). The family caregiver’s role in Alzheimer's disease. Neurology, 48(6), 2529.

International Academy of Wellness - Biofeedback. Retrieved December 18 2010, from http://academyof wellness.com/front-page/biofeedback.html.

Johnson, D.W. (1967). The use of role reversal in intergroup competition. Journal of Personality and Social Psychology, 7,135-41. 


\section{Challenges of Care giving Alzheimer's Patients}

Johnson, D.W. and Dustin, R. (1970).The initiation at cooperation through role reversal. Journal of Social Psychology, 82,193- 203.

Johnson, K. (2006). Interventions work for Alzheimer's caregiver's. Clinical Psychiatry News. Mar 1. Retrieved from http://www.thefreelibrary.com/Interventions+work+for+Alzheimer's+caregivers.a0149222.

Kalantari, F.M. (2010). A study to assess the effectiveness of biofeedback on anxiety and Stress among cancer patients of two stages and their caregivers. Unpublished Doctoral Dissertation. Mysore: University of Mysore.

Kasper, D.l., et al, (2005). Harrison’s Principles of Internal Medicine. Vol II, (pp. 2393-2398). USA: Tata Mc Graw Hill Company.

Kipper, D.A. (1992). Psychodrama: Group Psychological through role playing. International Journal Group Psychother.42 (4):495-521.

Lee,S.L, Coditz, G.N., Berman,L.F et al. (2003).Care giving and risk of Coronary heart disease in U.S.women: A prospective study. American Journal of Preventive Medicine.

Marieb (2006). Essentials of human anatomy \& physiology. New Delhi: Pearson Education, 245.

National Alliance for care giving and AARP. (2005). Care giving in the U.S. http://research .aarp.org /il/us-care giving.

Nettina, S. M., (2006). Lippincott: Manual of Nursing Practice. (pp.191-93). Lippincott Williams \&

Wilkins: A Wolters Kluwer Company.

Park, K. (2009). Park's textbook of preventive and social medicine. (pp. 43). India: Banarsidas Bhanot Publishers.

Pierce, et al. (2009).Care givers' experience: bimonthly Participation in a year - long research interview Process. Journal of Neuroscience Nursing, Retrieved November 22, 2010, from http://www.highbeam. com/doc/1G1-205906637.html

Quayhagen, M., Quayhagen, R.R,. Corbeil, et al. (2000).Coping with dementia: evaluation of four non phramacologic interventions. International Psycogeriatrics, 12 (2-4), 249-265.

Rabins, P.V. \& Kasper, J.D. (1997).Measuring quality of life in dementia: Conceptual and practical issues. Alzheimer Disease and Associated Disorder,.11 (6), 100-104.

Raley, W.E (1997). The family caregiver's role in Alzheimer's disease. Neurology.

Reeves, Roux \& Lockhart. (ND) Medical Surgical Nursing. (pp.293, 329-330). Tata Mc Graw Hill Company.

Sanders S \& Morano C. (2008).Alzheimer,s disease and related dementias. Journal Gerontol Soc Work, 50(1), 191-214.

Stein M.B \& challan, M.L. (1982). An excellent resource is the use of Psychodrama and sociometry, 35,118- 129.

Szri. (2008, September 21). In support of Health-Alzheimer; Silent killer of the minds. [Letter to the editor].The Hindu. 


\section{Challenges of Care giving Alzheimer's Patients}

Teri, L.Gallgher -Thompson D: (1991).Cognitive - behavior intervention for treatment of depression in Alzheimer's patients.Gerontologist.31:413-416.

Thompson C, Briggs M.(2000).Support for carers of people with Alzheimer's type dementia. [Cochrane Database Syst Rev] Retrieved February 26, 2011, from http://www.ncbi.nlm.nih.gov/pubmed/10796545?ordinalpos=1\&itool=PPMCLayout.PP $\mathrm{M}$

Waliser M, et al. (2001). The experiences and Challenges of informal caregivers: Common themes and differences among whites, blacks, and hispanics. Gerontologist .41(6), 73341.

Yaffe M J., \& Orzeck P(2008). Family physicians perspective on care of dementia patients and familycaregivers. Can Fam Physician ,Vol.54,7,pp1008-1015. Retrieved November 11, 2010, from http://www.cfp.ca/cgi/content/full/54/7/1008

Zarit SH, Stephens M P, Femia EE.(2003). The validities or research finding: the case of interventions with Caregivers. Alzheimer' Care Quarterly.4, 216-228. 